\title{
producing persons and developing institutions in rural Ireland
}

\author{
A. JAMIE SARIS—National University of Ireland, Maynooth
}

\section{IN MEMORY OF JOHN HAMILTON}

John could never grow weary of listening to Yellow Willy telling how he'd actually seen the Taj Mahal.

It was big, John, and shining. Six times as big as the courthouse and the town hall put together. As big nearly as the mental hospital.

Benedict Kiely, "Soldier, Red Soldier"

This article is part of a project investigating the cultural and historical relationships between St. Columba's Hospital (a mental hospital in the west of Ireland, in Sligo town) and a market town and its environs within the two counties-Sligo and Leitrim-served by this institution.' For the purposes of this study, I call this market town "Kilronan." Kilronan has been predominantly English speaking for more than 200 years, thanks to the early development of an intensive flax industry, although some nearby areas retained Irish as a hearth language well into the 20th century. Today, about 1,600 people live in Kilronan and its environs. The region possesses a long-standing association with the mental hospital in Sligo town dating back to the institution's construction in 1848, near the height of Ireland's Great Famine. Currently, Kilronan and its environs have a maturing psychiatric infrastructure geared toward absorbing into the community individuals formerly housed in the asylum. This concatenation of historical and ethnographic realities in Kilronan provides the oppontunity to understand how local knowledge of disordered persons is situated within a complex institutional relationship between a town and a mental hospital, as well as within a broader context of a colonial, then a postcolonial, periphery transforming along recognizably modern lines (Saris 1994, 1996, 1997). ${ }^{2}$

I examine two interactions between a community psychiatric nurse, whom I refer to by the pseudonym Terrence $\mathrm{O}^{\prime}$ Donnell, and two local men receiving services from St. Columba's Mental Hospital. Terry is an amiable married man with six children. In addition to his regular

In this article, I examine a community psychiatric nurse's highly commodified descriptions of the activities and interests of two clients of a mental hospital in rural Ireland. These examples show an intimate relationship between a discourse of economics and a discourse of rationality that can also be discovered in sources connected to the history of Ireland's mental hospital system. Using these and other connections, I argue that the distinctive utilitarian rationality associated with modernity, as well as reactions to it, can be promulgated and maintained at a local level through means other than economic markets. At the same time, I explain how the mental hospital now has a place within a local moral world. These two insights provide a novel perspective on a venerable debate in social scientific work on Ireland (and, by implication, many other peripheral areas of the global economy), that is, if, how, and in what respects the place has "modernized." [asylums, Ireland, rationality, modernization, commodity logic]

American Ethnologist 26(3):690-710. Copyright @ 2000, American Anthropological Association. 
job, he keeps a small farm (a long tradition for nurses in this area), where he runs cattle and sheep on 15 acres of medium-quality land a few miles outside Kilronan. In general, Terry seems to get along with everybody. He is interested in the things that most folks in this area (at least most menfolk) find interesting, and he worries about those things that seem of general concern. Thus, he is passionate about the Gaelic Athletic Association, particularly Gaelic football. He likes playing cards twice a week-bridge rather than poker as a register of middle-class status. He smiles at the thought of rising cattle and lamb prices. He worries about bad weather, politics, and the economy. The fact that he farms on the side allows a degree of communication with many of his farming clients that would be otherwise unobtainable. Of necessity, however, Terry interacts with his clients in specific ways, that is, visiting them to provide mental health services. This entails checking on their general living situation, monitoring their health, and encouraging them to take their medication.

Terry became one of my key informants, and he often glossed for me widely held sentiments attached to those availing of mental hospital services. My basic premise in this article is that the leakage observable in these glosses between discourses associated with the movement of money and commodities and that of rationality points to the importance of the mental hospitals that sprang up throughout the island during the 19th century in any discussion of the penetration of commodity logic into peripheral areas of Ireland. This sense is supported by aspects of the history of Ireland's asylum system as well as some of the ways that people from Kilronan use money to think about locals whose biographies have intersected with the institution.

\section{modernity and rationality}

Insofar as this article touches on the issues of the penetration of commodity logic into peripheral areas of Ireland and its implication for so-called peasant mentalities, I speak to a large body of work beginning with a section in Marx's Capital (1972: ch. 25; see also Hazelkorn 1989). In recent years, an important part of this debate has taken the form of varying perspectives on the early social anthropological collaboration of Conrad Arensberg and Solon Kimball, the fruits of which, The Irish Countryman (Arensberg 1937) and Family and Community in Ireland (Arensberg and Kimball 1940), became baseline studies for subsequent social scientific work in rural parts of the island. ${ }^{3}$ By and large, this literature has offered a fairly mechanical view of the penetration of the logic of the market and the making of modern mentalities, looking at such indexes as farm size, number of family farms, the development of capitalist relations, and the reliance on a cash economy in rural Ireland in order to figure out how, or why not, this area modernized (see Curtin 1986; Gibbon 1973; Hannan 1979; Shutes 1987, 1989).

Aspects of this debate are of obvious concern to sociocultural anthropology in general. Notions of traditional and local, for example, historically have existed in the discipline as both fields for and objects of study, perhaps more strongly in the anthropology of Europe than other places. These terms and their referents have been contrasted with and implicitly threatened by others-modern, market, and cosmopolitan (see also Appadurai 1988, 1996; Bendix 1997). A central axis of this contrast has been a definition of rationality that becomes more recognizably informed by economic calculation as one approaches the modern and cosmopolitan end of this polarity (Sahlins 1976). Supposedly, an entity called "the market," conceptualized in Liberal Economic theory as a historical actor in its own right, encourages the transformation of people, places, and life worlds toward the modern and cosmopolitan by reproducing its distinctive rationality in other spheres of life. This argument has a recognizable parallel: a defining feature of individual and social backwardness is economic irrationality. Development, modernization, and rationalization, then, are all of a piece. In the end, even as sophisticated a thinker as Habermas accomodates this aspect of Liberal theorizing about rationality, arguing that the 
subjective experience of reason as a mode of justifying action in the world is an achievement and one of the diagnostic features of modernity (1984:210-216, 1987:250-275, 480).

An example of this type of thinking on modernization is apparent in social scientific work on Ireland. In his well-known essay, "The Modernization of Irish Society, 1848-1918," Joseph Lee argues, among other points, that the south of Ireland modernized without industrializing while the north industrialized without modernizing-precisely because individuals in the south behaved in an economically rational fashion when the opportunity presented itself even though they did not develop an industrial base, whereas those in the north industrialized while maintaining primitive, irrational animosities (1973). In this sort of argument, registers associated with rational choices within a particular economy are understood as moves toward the modern and necessarily away from the traditional, where rational, economic, and modern are understood in the ways that those who control the so-called developed economies of North America and Europe conceive them.

I extend this debate about rationality, commodification, and modernization in Ireland by examining how state institutions, like the asylum, have been important but still underappreciated influences in importing the distinctive valorization of utilitarian economic reason as the highest expression of modern rationality (what Weber called Zweckrationalität; see 1978) into the island's peripheral areas (see also Weber 1976). I develop this examination around an example of what Comaroff and Comaroff call, in a different context, a "human vehicle of a hegemonic worldview" (1991:310). I write about a nurse who, I argue, is connected to a two-century-old institutional project involving the valorization of a distinctive form of rationality and being in the world. Understanding aspects of the relationships between a community psychiatric nurse and some of his clients, alongside issues in the historical development of the mental hospital system in Ireland, provides a novel way of thinking about what has been an ongoing, multilevel process of historical agents confronting a developing world system of market and political relationships within a colonial (later independent) state structure. ${ }^{4}$

\section{saintly labor}

Off an unpaved side road barely visible on the Ordinance Survey maps of this area, down a little rutted dirt lane, sits a cabin that might have come out of a Bord Fáilte postcard. ${ }^{5}$ The home and farm of Mary McTaggert and her son John is more remote from Kilronan than its nine-mile distance would imply, although attempting to slog through this territory in low gear is a good way to obtain an appreciation of relative distance in the Irish countryside.

The McTaggert cabin is modest and in need of another coat of whitewash. The main room is about 13 by 15 feet, bare flagged, and dominated by a huge old-fashioned hearth. Two rooms, one on each side of the main chamber, are barely visible from the front door. An array of items on display in both the main living area and the two smaller rooms adequately make the point that the functional division of space is only imperfectly realized in this house. This spatial disorder was one of the first things commented on to me by Terrence $O^{\prime}$ Donnell when he heard of my interest in the family, but the mother and son do not seem to mind it. The house was cold that early spring morning when I first visited-the small fire providing warmth only in a six-foot radius.

John entered just as Mary, a tall woman wearing a black shawl, was making me tea. John is in his midtwenties, short with a round face (one very different from his mother's angular visage). He has his mother's intense blue eyes, but, unlike hers, they often appear oddly unfocused, as if he is always in the process of remembering something important. $\mathrm{He}$, too, was dressed in black. He was also muddy from his wellingtons to the cloth cap on top of his head. One of his cows had been ill the night before, and he was up early to check on her. The dress of both the 
mother and the son gives the same impression as the house-a bit threadbare, but it keeps the wind at bay.

John McTaggert is known locally as "a great man for the cattle," a phrase that codes much interesting information about him. First, it means that he is a very quiet man, particularly when an ethnographer does not share his passion for bovines. It also means that, while the circumstances of this family are in a certain sense poor, their material circumstances do not measure their local success. As I came to know this area better, I was increasingly struck by how respected the young McTaggert is. There is more admiration than irony in his neighbors' usage of "a great man for the cattle." In most contexts, this understanding of John (particularly at his relatively young age) is a form of sincere compliment.

This designation acknowledges his assiduous cultivation of a natural sympathy with bovines as well as serving as a good excuse for his discomfort with callers of the two-legged variety. As an older neighbor commented about John, "Ah, he's quiet, now, and he's good with the cattle. That lad is a saint." This social deployment of the term saint overlaps and contrasts in interesting ways with the manner in which it was used in County Clare of the 1930s (Arensberg and Kimball 1940:173-176). In that place and time, Arensberg and Kimball found the word saint was used as a sociological affirmation of a social role well filled, but only for the old. It is worth noting that only his older neighbors refer to John in this fashion (indeed, due to emigration, there are relatively few young faces in this particular area). The idea of success in the sense of a well-lived life may be the key that connects the use of saint in Kilronan and County Clare. In any case, John seems to accept his avocation for cattle and cultivates this virtue in quiet solitude. ${ }^{6}$

The young man is not a total recluse, however. Like clockwork, every Thursday evening after the Kilronan Cattle Mart (the formal weekly venue for the purchase and sale of animals), John can be found at Bridey's, a farmer's pub just at the edge of town, where he faithfully consumes three pints of stout over the course of two-and-a-half hours, silently and with only the most perfunctory acknowledgment of the other patrons. He is not, in the language of the area, "a man for company," but that personality trait, too, is in line with local expectations of "a great man for the cattle."

John McTaggert has also spent some time in St. Columba's Mental Hospital. During the spring before I arrived, a promising calf died suddenly, and the young McTaggert voiced increasing worry about certain financial obligations that he would be unable to meet. He had previously borrowed money from a neighbor to purchase another animal, but despite his success as measured by that calf's growth, the softness of the market for cattle had prevented its resale at any real profit. He had been counting on the sale of the dead calf to help repay this debt and meet his day-to-day needs. After this setback, John became more uncommunicative than usual with his mother, who became particularly worried when he began to lose interest in food.

A few years previous to all this, Mary's bachelor brother, Séamas, who lives nearby, was also hospitalized in St. Columba's after a similar set of financial worries. Séamas went through a series of financial setbacks in the management of his farm, followed by a greater than average degree of social withdrawal and a loss of interest in food. Séamas was then hospitalized in St. Columba's with the encouragement of Terrence O'Donnell, who convinced Mary to persuade her brother to "sign himself in." In any case, when John seemed to be having similar difficulties, Mary became concerned enough to call this same community psychiatric nurse.

In the end, Mary cajoled John into taking a "bit of rest from the farming." He was hospitalized briefly, then released on medication. Although he had been out of the hospital for about a year with few difficulties, at the time when I first met with John, his therapeutic team worried that he was severely thought disordered. He was extremely uncommunicative, except with, and somewhat less rarely about, his cattle. He greeted them in the morning and occasionally talked to them into the night. The team felt that they could do little more than monitor John and his medication. They continued to admonish him to take his tablets, and they continued to be 
concerned that all signs_ everything from his lack of social contacts to the general disorder of his living conditions-did not bode well for his continued ability to manage outside of the hospital.

\section{the measure of a man}

John's mother was central to the process of getting him to "sign himself in," but after his initial hospitalization, the relationship between McTaggert and his cattle became the salient point for most of the actors in this social drama. John's therapeutic team understood the importance of cattle to his existence-including calling them by name and occasionally talking to them into the night - to be at odds with a modern vision of mental health. On the other hand, Terrence O'Donnell knew that for most people of his area, John's cultivation of cattle for company is explanation enough for both his peculiar success with his charges and his human peculiarities of muttering to himself or his beasts and only rarely talking to other people.

Indeed, Terry also knew not only that John's peculiar virtue for cattle is widely acknowledged, even celebrated by some, but that his advice, on the rare occasions he is willing to offer it, is taken very seriously even by much older individuals-an anomalous flow of farming expertise, the exceptional quality of which is difficult to convey in the absence of having lived for some length of time in more traditional parts of rural Ireland. Terry was also aware that John is sought out by many of his neighbors for unofficial veterinary services, everything from tending persistent small wounds to assisting with a difficult calving.

These interactions and the talk about them are complex. In the first place, John's advice and ministrations are decidedly not professional services in the sense of an expert giving a timed amount of work or advice in exchange for a fee. Indeed, the direct offer of money in such a situation would be somewhere between rude and difficult to imagine. Nonetheless, the receiver clearly feels indebted for this sort of work and might well provide some financial considerations at a later date. The social faux pas develops out of the suggestion that the offer of compensation, particularly monetary compensation, was the price of the expertise or the cure. This sensibility has been documented similarly for certain kinds of healing, among other kinds of expertise, in a variety of sources for Ireland, including classic ethnography (e.g., Arensberg and Kimball 1940:258-263) and literature (e.g., Thompson 1974:134-137). I encountered a similar attitude early in my fieldwork when I offered cash in exchange for some help provided to me by an individual who was later to become a close friend. He refused the cash and admonished me gently, "That would take all the good out of it."

In the event, McTaggert's period of hospitalization became something of a local non-event (see Fogelson 1989), mentioned neither in day-to-day conversations nor in local stories about John. This nonchalance about asylum committal can sometimes be found in poorer areas around Kilronan whose residents have historically used the mental hospital as part of the social safety net. People from McTaggert's area, though, while not very well-off, consider themselves too respectable for this sort of usage, tending to find any connection to the asylum very stigmatizing. Nonetheless, as far as I was able to determine by both direct questioning and observation over several months, John's temporary absence seems to have little altered his neighbors' relationship with him. His distance from regular human concerns and from most human company instead supports the impression in the area that he is saintly, good, someone who "bears malice toward no man."

These peculiar powers marked by such terms as saint, moreover, have specific attributes. Like many spots on the landscape named after Catholic saints who are reputed to have special powers, John's expertise with cattle is, ideally at least, freely available to all in specific circumstances (see Taylor 1995:35-76). Indeed, such powers exist in some tension with the idea of a price in currency-that is, the common ability ascribed to money to quantify and 
render exchangeable objects and capacities that are qualitatively different (Simmel 1990:1 18-125). This remove of John's abilities from the realm of price is accompanied by other qualities. Like other figures with peculiar powers in narrative and folklore, John has a sort of dispensation out of established hierarchies, in this case giving advice to older people who have more agricultural experience.

\section{institutional transformations}

By the time I had arrived on the scene, a relationship of a sort had grown up between Terrence $\mathrm{O}^{\prime}$ Donnell and this local saint. During my first visit to the field, Terry was calling in on McTaggert professionally every other week, keeping after him to take his medication, and worrying privately over the disordered state of the McTaggert residence. He continued in this vein for more than a year, and he was still in contact with the McTaggert family during my work in the mid-1990s.

Terry conveyed two rather different senses to me when I questioned him about John. Professionally, he worried about what he saw as the young man's lack of social contacts. At the same time, the community psychiatric nurse also genuinely admired the young man's abilities with cattle. For example, Terry had seen John's margins on the sale of his charges frequently buck the downward pricing trends at the weekly Mart in Kilronan, no mean accomplishment given the state of the European Union'sagricultural sector in the late 1980s and much of the 1990s. Indeed, it was this ability of McTaggert that Terry stressed to me after he had gotten wind of my first meeting with the young man, and it was one that he continued to emphasize when John came up in our conversations:

He has a very good reputation in the area, though. For knowing cattle I mean. Anyone, you know, can buy cattle, feed them, and make a few bob at the end of the year. But, you have to really know cattle to spot the right one to buy, and to buy at the right time... to make a good profit, even when things are bad, like. ... He's that kind of man.

Terry is also one of the few people outside of this area that can engage the otherwise silent young man in a verbal exchange that can properly be called a conversation, a facility I admired enviously. Terry accomplishes this feat through a shared interest in and knowledge of cattle. Terry, however, translates the local esteem for one of its saints into an idiom of money and livelihood. This translation is an implicit challenge to the locally acknowledged basis of McTaggert's abilities. Recall that John's saintliness is tied to an avocation that, of necessity, is neither identical with nor reducible to the strictly economic aspects of his life. While part of John's local reputation is derived from his success on Mart Day, this success merely testifies to a locally recognized virtue rather than acting as the endpoint of a strategy of maximizing marginal utility. In other words, the economic success is an epiphenomenon of a particular lived ability, not its telos. Indeed, one of the most important aspects of his social life as a "great man for the cattle"-unofficial status as veterinarian and agricultural advisor-is expressly noncommodified as a condition of his ability to perform these services. When John's neighbors seek his advice, they acknowledge his avocation, and the direct offer of money for this quality would, ironically, undermine the possibility of its existence. Terry's assessment of John shows a subtle but substantial shift from a high regard for John's well-lived life to admiration for his livelihood, maximized within a freely contracting market.

Terry also had other things to say about the McTaggert family. From an early point, Terry recounted Séamas's difficulties of several years earlier. Certainly, by the time I came on the scene, he had begun to narrate the McTaggert family in a specific fashion: "There's a weakness there all right. He's a cousin down below, and an uncle who has problems with his nerves." The simplest interpretation of Terry's use of this genetic idiom would be to see it as the statement of a biomedical paraprofessional who has absorbed and mechanically applied some of the latest 
research into the genetic nature of mental illness. Indeed, many medical professionals in the hospital see a hidden biological wisdom in this reckoning of genealogical connections for such faults as criminality or insanity. This local recognition of blood ties, they imply, foreshadowed official understandings of mental illness in a psychiatry that has become ever more scientistic and mechanically deterministic in the last 20 years. "They [the country people] knew more than we gave them credit," one older psychiatrist whispered to me knowingly on a tour through the hospital as he glanced meaningfully at a woman who had made the institution her home for nigh on 40 years. He went on to explain that he had discovered how this woman had relatives in the two generations before her interned in this same institution, clearly implying that mixed with the dross of folk belief were pure nuggets of modern biological wisdom.

The idea that problems such as criminality, alcoholism, and insanity tend to run in families, however, has other traditional resonances often ignored by such translations. Arensberg and Kimball, for example, discuss such genealogical wisdom as an integral part of their understanding of family conflict. They describe a scene in which, after committing his wife to the mental hospital in order to obtain her property (according to some), a devious husband is visited by his distraught wife's very angry relations:

They came in and said that he was lucky he was going to escape with his life. No one in their family had ever been in the asylum and no one belonging to them had ever been insane or robbers and that he was trying to black them with the disgrace of it. ... They said that all the people belonging to him were thieves, and that two of them, two uncles of his, his mother's brothers, were convicted for robbery and that all his people before him had been insane. .. . They gave him a good hiding. [1940:121-122]

In this vignette, the crime of one family against another is not merely the unjust imprisonment and harassment of a single person but the fact that the committal of a family member to the asylum is bound to be taken up in local gossip in a stigmatizing way. For the offended family, it is important, therefore, that local gossip be turned against the offender. They do this in part by asserting his own genealogy of disorder (uncles who were robbers, all his people were insane). In other words, it is social memory and the potential for public narration of suspect genealogies that are relevant, not abstract biological connections as such. Consequently, such local knowledge, and the ability to articulate it, is itself a source of power. Because, in many places around Kilronan, family names cluster together, the sort of knowledge that Terry articulates about John and Séamas can conceivably stigmatize an entire area.

This sort of knowledge becomes even more difficult to categorize as either modern or traditional considering that hospital staff viewed the ability to reckon genealogical connections among clients as an important mark of having gained local knowledge. Those nurses who became particularly skilled at tracing these connections gained a certain narrative immortality in the institution's lore. Such individuals are remembered in a very interesting fashion. James McDonagh, an older nurse, recalled one such person for me:

\footnotetext{
I knew a man in Sligo now. He was. . . he was. . . Deputy Head Attendant, and he was intelligent. He was a saintly man, and he never married. Tom Fallon was good. First of all, he knew every patient by name - every one of a thousand, over a thousand. And secondly, he knew his uncle - his uncle was there, and he's a son [i.e., he could situate the patients genealogically]. And I remember always when a patient came through there was, lusing Fallon's voice] "Ah, we've got his old uncle down the House. ${ }^{8}$ There's an old uncle down the House." And, he'd open the door and say [using Fallon's voice], "The doctor's wasting his time with that fella, he'll do no good." He'd be great on the state of health once the patient got sick [i.e., prognosticating] [using Fallon's voice]: "It'd be no good Jimmy la psychiatrist] treating him. It's no good, ah, no good--he's got an uncle down the House."
}

Tom Fallon, like John McTaggert-quiet and solitary-is remembered for his profound knowledge of the genealogical relationships of those admitted to the hospital and for a peculiar ability to foretell likely outcomes of the new arrivals. Variations of the term saint are applied to the type of expertise possessed by both men. Both men also have a very interesting relationship toward established hierarchies. McTaggert provides sought-after advice against the gradient of longer agricultural experience, while Fallon's voice is marked by McDonagh in the text above 
through the use of the Christian name of a psychiatrist-and that in the diminutive. Such familiarity is a deliberate inversion of a strict institutional hierarchy that to this day is rarely violated. ${ }^{9}$

\section{farm troubles}

Later in my fieldwork, on a "hard" November day-clear, bright, and chilly-Terry consented to take me along on one of his rounds "out the country." Our third stop was a two-story, ramshackle farmhouse, close to an old thatched cottage that once housed people but now serves as an out building. Victor and his wife Nuala are the sole occupants of this 25 -acre farm, their eight children scattered throughout Britain's former empire. One son, a priest in Roscommon, and one daughter, a civil servant in Dublin, regularly visit the old couple, but the other six have made their homes in such diverse places as London, Australia, New York, and New Zealand. When they and the families they are raising across the seas come home for visits, it is cause for celebration.

At the time of this research, Victor was past 70 and proud of the fact that, until very recently, he had been able to run his small farm successfully without assistance. The immediate cause of Terry's visit was Victor's brief period of hospitalization at St. Columba's for depression during the previous summer. At the end of the summer, he was discharged on medication to the community. His psychiatric team, however, keep a special eye on him because of a fear, ungrounded in direct evidence as they admit, that he may be more severely depressed than he lets on. Victor, however, talks about whatever distress he may be suffering in vastly different terms than the professionals who are interested in him. He speaks of "losing his courage,"10 occasioned by incessant worry over the price of cattle, which had been falling steadily in the past years, and he complains about his declining physical health as he suffers from farmer's lung. ${ }^{11}$

With the light from a midmorning sun streaming into the airy kitchen of the farmhouse (this room and the adjoining bedroom being the only two used by the old couple, reproducing under slate the living arrangement that they once shared in their youth under thatch), I recorded the following conversation between Terry and Victor concerning the proximate causes for Victor's distress and the rational ways one might go about addressing such problems:

Victor: You may not be familiar with the farming business, but the prices has been bad, very bad. I've been feeling a lot of pressure, trying to make decisions with these prices.

Terry: I know very well, very well indeed. I run a small farm myself as a sideline. The prices have been very bad.

Victor: That they have. I'm very run down because of it. [worried pause] . . Sean Og, that would be Sean MacDermot, just down the road, was forced to sell a bullock last week for $£ 220$. He made just eight quid, eight quid mind you, for 18 months' work. A man can't live on that, sure he can't.

Terry: But sure now, if the farm's causing you that much trouble, couldn't you sell up? The whole stock, I mean. Go to the Mart next week and get market price for the lot. That way you've no worries, no feed for the winter, nothing. [This is more than idle chat, for Victor's farmer's lung means that continued exposure to hay could have severe consequences.]

Victor: But then prices might improve.

Terry: Aye. They may or they may not. We never seem to talk about them when they're good, though - only when they're bad. [pause] Still, you can always hold on to them, until things get better, I suppose.

Victor: Aye. But you can't do that always.

Terry and Victor share the same vocabulary about farming, but their terms are not precisely mutually translatable. For Terry, the farm is a resource to be rationalized or, as a last resort, liquidated to cut losses. In the late 1980s, for example, he was convinced by the county agricultural advisor that the market for cattle was going to be depressed in the near future, and in his own words he "got into sheep" (i.e., diversified), whose care and maintenance in 
comparison to cattle is considerably less time consuming and expensive. This advice turned out to be propitious because the market for lamb has stayed relatively healthy on the back of demand from the Continent (Shutes 1989). Meanwhile, the continuing rationalization of European agriculture and the Bovine Spongiform Encphalopathy (BSE) crisis of recent years have hurt small beef farmers, like Victor, more than any other group.

Terry, on the other hand, is precisely the sort of farmer who has benefited from these transformations in agriculture. He recognizes his land as an economic enterprise, the success or failure of which is dually dependent on his own efficiency and productivity as well as the behavior of a general market for his commodities. He takes seriously the recommendations of state-supported agricultural officials. In fact, he sees his "bit of land" mostly as a form of economic diversification, a supplement to his wage. Terry also believes that an added benefit of his farming activities is the understanding it allows him of the lives of many of his charges in the community.

To some extent, Terry's farming activities do allow for this sort of communication, but his orientation to such activities also engenders certain misunderstandings. Victor, for example, sees his farm as more of an avocation than an employment. His farm can support 20 cows, and, to him, there is something unnatural in running sheep on such land. For Victor, sheep are resorted to by farmers with poorer land than that to which he has access. Indeed, the selling of a farm, in Victor's understanding of the world, is a form of social death contemplated only in extreme circumstances, if at all. On the other hand, Victor has neither the resources to sit out the price cycles nor the desire to look at his land solely in terms of the cash flow it can provide for him. Sitting out the price cycles may not be possible as more and more of the European Community farming sector is dominated by agribusinesses that can operate successfully on much slimmer margins, at least in the short run, than can the family farm (Curtin 1986).

Terry, while not insensitive to Victor's dilemma over his land, appreciates the small farmer's situation only in more or less intellectual terms. As we continued our discussion of the old farmer and his predicament in Terry's car on route to our next stop, the community psychiatric nurse admitted that Victor's prospects looked bleak: "I don't know what he's going to do. An auction is an admission of failure. All the neighbors know that you are out of the farming. . . Aye, there's plenty of that here all right-worrying about the neighbors knowing your business." At the same time, Terry continued to cast Victor's difficulties in highly commodified terms:

If he really wants to sell off, though, he can always go to the Mart, and get the market price for his cattle. He's got to be more careful, though, with putting an ad in the paper or getting one of his neighbors in on the deal. There are men who look through the papers-"tanglers" we call them-who'll come to your place, all right, but will do everything they can to talk down your stock. Pointing out this or that fault, worrying about the prices. He's the type that would be taken advantage of.

Victor can be taken advantage of for any number of reasons. If, for example, he sells his farm, it will likely be in extremis, and, therefore, he will be in a poor position to bargain. Victor's main handicap, though, is not that he lacks fluency in the language of commodities. Indeed, he is recognized in his area for "knowing the value of a pound." Instead, Victor has not naturalized a certain valuation of economic productivity. I never heard him say anything that implied he was contemplating, or would contemplate, a life outside farming. To this extent, he understands such work not as livelihood but as life.

\section{the progressive farmer}

One of the questions that springs up in these two scenarios is whose voice is more authentically "traditional" and "local," and the answer that is most often given in ethnographic research in rural Ireland, in situations resembling the last example at least, would be Victor. Consider the following description of the seeming foreignness of a local entrepreneurial family in Inishkillane by Hugh Brody: "The traditions of the Irish peasant evidently do not encourage 
a hierarchical community.... The community therefore tends to be one group with more or less identical lifestyles, backgrounds and economic interests" (1973:205). Indeed, Victor's understanding of his land and his despair of the unsteady shoals of the market seem to imply he is physically, temporally, and spiritually apart from the realm of the modern; to that extent, in many ethnographies of western Ireland this understanding could be constructed as more typically Irish (see also Cresswell 1969; Scheper-Hughes 1982). The oppositional logic inherent in modernization thinking necessarily casts Terry into the opposing camp-an embodiment of a mentality that developed somewhere else. Similarly, the relentless watershed sensibility in this same way of thinking-its delight in before-and-after binaries-imbues Terry's understandings with the historical inevitability of the present and assigns the lives of Victor and John to the realm of the quaint on their way to extinction.

It seems to me, however, that such divisions are in no way supported by the data. Terry's credentials of localness, for example, are impeccable. He is the son of a local small farmer, who likes rising cattle prices and twice-weekly card games. His familiarity with farming, his involvement with the Gaelic Athletic Association (which is still taken in many circles in Kilronan as sufficient proof that one is "Irish in mind," as another local man wryly put it), and his reasons for seeking asylum employment- " The work was consistent and there was a pension at the end of it"-all display local sensibilities.

Even in the most narrowly defined cultural sphere, Terry's local, even traditional, credentials are still impressive. While he has only "school Irish," consistent with Kilronan's history as an English-speaking area, he has made sure that his three sons have inherited his passion for traditional sports, particularly Gaelic football. He is also justly proud of the fact that one of his lads has shown real promise on the tin whistle, in line with Kilronan's reputation throughout the region for the number and quality of its traditional musicians. Finally, his interactions with someone like John McTaggent, however complex and multivocal, confirm his qualifications as a local. One could not possibly imagine a stranger or "blow through" being able to talk bovine with a "great man for the cattle." What is needed, then, is a fundamentally more textured sense of tradition and locality to make sense of someone like Terry.

There exists a locally recognized distinction between individuals like Terry and farmers like Victor and John that speaks to some of these complications. One farmer of my acquaintance put it succinctly when I asked him to give me some idea of the people he knew from his area who worked in the asylum:

They would have been seen here as being very active farmers, very ambitious farmers. They would mix in the community through their farming activity, rather than their role as nurses. . . They would also have been seen as more interested in land than farming, like. ... Well, you see their economic situation was better than most of their neighbors, because they had a stable job. They could engage in more progressive farming methods because they had the backup of a job, a salary. . . Yeah, they were progressive farmers.

The observation that nurses who farmed "were more interested in land than farming" is of capital importance in this regard as it recognizes the local people's distinction between farming and land. Farming is a social activity traditionally bound up in an interlocking web of friendly obligations. Land is a potentially alienable thing, something to be rationalized and maximized. The opposition between progressive and traditional in the country exists within the town of Kilronan, say in the running of a shop, as the difference between pushed and easy going. Both pushed and progressive give the sense of living one's life within an idiom of maximizing productivity. Terry is progressive because he lives more of his life within this idiom, in comparison with someone like Victor, who does not.

This opposition operates in nearly every aspect of the respective lives of people considered traditionals and progressives, sometimes subtly, sometimes not. Terry's bungalow is as different from Victor's farmhouse as his recognizable success in rationalizing his land as a resource is from Victor's visceral commitment to farming as a value in and of itself. Whereas Terry 
understands and exploits the opportunity to discover trends by monitoring the buying and selling at the weekly Cattle Mart, Victor sees the Mart as a center for progressive emmiseration, as all it has done in most of his lifetime is undermine the possibility of farming as he learned it.

Finally, this opposition manifests itself in how historical transformations are recalled, such as the differences between the Cattle Mart and the old fair days that the Mart replaced. Progressives, like Terry, look back on the old fair days of their parents' time or their own youth as scenes of confusion and disorder, presenting ample opportunities for collusion that distorted the price of cattle. Indeed, some men use the term filth to describe this disorder of animals and humans in the streets, in the same sense that a nurse like Terry will occasionally use the term to describe the disordered habitations of certain clients. Traditionals, on the other hand, remember the conviviality of the old system whereby the town became a bustling, almost raucous, place for a few days, providing chances to renew acquaintances and celebrate the closing of deals with a few jars. ${ }^{12}$

\section{rationality, productivity, and the colonial asylum}

Terry's musings about his clients, as well as local perceptions of what sort of farmer he is, become even more interesting when examined alongside the 19th-century justifications for an asylum system in Ireland. The official entrance of the "lunatic asylum" occurred in 1815-16, when a Parliamentary Select Committee was ordered to determine the extent of what was seen as a growing problem of lunacy, particularly in rural Ireland (Select Committee to Consider the State of the Lunatic Poor in Ireland 1817). The Select Committee was charged with making recommendations on the advisability of constructing a formal system of asylums for the island. This committee was a gathering of luminaries and reformers from all parts of Ireland-magistrates, doctors, landed gentry, and retired military men. Despite their political differences, almost all of these men came bearing the same news: lunacy was on the march among the poorer classes on the island, particularly in the remote, ill-administered parts of the country. Furthermore, they insisted lunacy was connected to a penumbra of other disorders-of space, work, society, individuals, and relationships-and these areas, too, required attention.

The committee began by situating disorder and degeneracy in particular regions and populations and tracing the causes of this state of affairs. To this end, Thomas Rice constructed an argument regarding the causes of insanity by refracting a set of purportedly well known attributes of the Irish peasant through an emerging medical discourse of lunacy:

[Lunacy] is an hereditary malady and therefore likely to be extended. It is connected with scrofulous habits, also hereditary and therefore advances on a double principle. It is connected with the habits of the lower classes of people in Ireland who addict themselves to the use of ardent spirits; and it is connected also with the use of Mercury. These four causes are, a priori, sufficient to show that it is on the increase. [Select Committee to Consider the State of the Lunatic Poor in Ireland 1817:21]

With the exception of the reference to mercury, these are among the durable colonial images of the Irish that have survived in one form or another even in scholarly accounts of the island into the late 20th century (Murphy 1975). Beyond Ireland, they are also traits that have been pointed to by the rulers of colonial and postcolonial peripheries throughout the world as intrinsic handicaps to explain those populations' marginal relationships to the state and market economy (e.g., Arnold 1988; Butchart 1998; Comaroff and Comaroff 1991; Curtis 1971; Farmer 1992, among others).

The committee went on to trace some of the implications of this disorder for life and suffering in rural Ireland. Denis Browne, a magistrate from County Mayo who had earned a reputation for savagery in the suppression of the 1798 rising by hanging large numbers of peasant rebels, painted the following sympathetic, poignant, almost lyrical picture of lunacy among the rural poor: ${ }^{13}$ 
There is nothing so shocking as maaness in the cabin of a peasant, where the man is out laboring in the fields for his bread, and the care of the woman of the house is scarcely sufficient for the attendance of the children. When a strong man or woman gets the complaint, the only way they have to manage is by making a hole in the floor of the cabin for the person with a crib over it to prevent his getting up, the hole is generally five feet deep, and they give the wretched being his food there, and there he generally dies. Of all human calamity, I know of none equal to this in the country parts of Ireland which I am acquainted with. [Select Committee to Consider the State of the Lunatic Poor in Ireland 1817:23]

The ethical and social imperatives behind intervening in this human calamity were that the country was already overburdened (according to these same authorities) with the problems of pervasive poverty rooted in idleness, incomprehensible factional violence, and a majority religion that encouraged irrational superstition. Browne's portrait is of a population both helpless and dangerous, whose capacity for productive labor is retarded by degenerate handicaps and primitive habits. ${ }^{14}$ The disorganization in the scene encompasses everything from the space within the cabin to the economic disarray that follows in the wake of such problems. In turn, the sort of rationality that Rice and Browne seem to have in mind for the Irish peasant tacks easily between the development of individual faculties, economic potential, and new social norms. Browne's richly detailed scene condenses all these issues, implying that the amelioration of medicalized irrationality in Ireland would require a multilevel reorganization of space, time, and person. Finally, Browne's description elevates the social and moral issues surrounding lunacy above others that might also have been the target of official intervention in early-19thcentury Ireland.

In the face of such evidence and moral suasion, the committee concluded that the problem of lunacy in Ireland, especially among what were called the lower orders, required an institutional approach organized along rational bureaucratic lines. Under the supervision of a central inspectorate, the hospitals would institute a specific regimen-moral therapy-that would redeem the pathological irrationality of the inmates by stressing self-control, the functional organization of space, and the linear periodization of time (Saris 1996, 1998). In other words, this regimen would parallel the organization of persons, environments, and resources necessary for the generation of wealth in factory production.

\section{developing institutions}

The committee of 1815-16 recommended that seven moderately sized hospitals devoted solely to the treatment of idiots and lunatics be built (and three other extant hospitals converted) to form the District Lunatic Asylum System for Ireland. The new construction began in earnest in the 1820s. The number of beds thus provided (under 1,000 ) would, it was felt, be more than adequate for the needs of the island in the foreseeable future. The bureaucrat responsible for implementing this system was an ambitious chief secretary (later home secretary and, finally, prime minister) named Robert Peel, a man whose shadow loomed ominously over 19th-century Ireland. A bitter opponent of Catholic emancipation and other reforms in Ireland, Peel was not a friend of Irish self-determination. Among his enduring legacies was the creation in 1833 of a paramilitary force that eventually became the Royal Irish Constabulary, called "Peelers" well into the 20th century. ${ }^{15}$ Peel also pushed through a Poor Law for Ireland in 1838 with the purpose of confining and reforming the indigent.

The development of Ireland's asylum and police systems has other interesting connections. Both systems have their genesis in two committees meeting almost at the same time, between 1815 and 1817 , during a period of unrest in rural Ireland (for the asylum system, see Finnane 1984 and Robbins 1986; for the Royal Irish Constabulary, see Broeker 1970). Particularly after the Great Famine, in more peripheral areas of Ireland, both of these institutions recruited the sons of Catholic tenant farmers to fill their lower ranks, eventually providing one of the few avenues of social mobility other than emigration as the rural social structure became increasingly rigid in the second half of the 19th century (Gibbon 1973; Inglis 1991). Throughout this 
period of institution building, the colonial bureaucracy clearly anticipated that these lower positions in the state bureaucracy would acculturate the individuals who occupied them and the society at large, as asylums and police pursued their particular mandates to contain disorder. Directly and indirectly, their own rank and file were both means and ends of this discipline, providing local examples of daily habits and comportment for a population that was seen as morally, socially, and economically degenerate (Curtis 1971; Lebow 1976; Saris 1996:544546).

The asylum system was one of the most considered colonial interventions into the affairs of Ireland. The colonial administration in Dublin Castle, for example, boasted later in the century that it had seen the necessity of these institutions "in advance of the public appreciation of the problem" (Larcom Papers 1865). As a system, the regime for treating lunacy was only the beginning of a larger bureaucratic assault on the Irish people, insofar as it was the first of a long line of centrally controlled bureaucracies aimed at specifically Irish problems (Inglis 1991). The Irish Constabulary, for example, was constituted as a formal body in 1833, becoming "Royal" in 1869 (Broeker 1970). A national school system opened in 1834 to promulgate English and supplant vernacular Irish throughout the island. The Ordinance Survey of 1833-39 was intended to completely map and name (in English or transliterated Irish) every site of importance in Ireland, making the island one of the best mapped areas in the world during that time period. ${ }^{16}$ Finally, a full, nationally administered workhouse system began in 1838, replacing the old Houses of Industries run by local corporations (Feingold 1984). ${ }^{17}$ By the middle of the century these institutions, along with the so-called devotional revolution in the Catholic Church (Larkin 1972), ${ }^{18}$ were disciplining daily practices toward recognizably civil (read middle-class British and Western European) lines (Inglis 1991).

These institutional moves to discipline place and person in the Irish countryside paralleled moves toward the modern in the sense of integrating rural Ireland into the state economy. The period of asylum building from the 1820 s to the 1870s, for example, coincided with the development of a dense railway network on the island (Lee 1973; MacDonagh 1977; Mulligan 1983) as well as the nascent growth of various industries. At the mid-point of this period, famine annihilated the poorest 20 percent of the Irish population. While the debate as to whether the Great Famine was a weapon in the arsenal of colonial oppression is a fraught one, no one denies that the burden was unequally distributed socially and spatially (for a sense of the debate, see Curtin 1994; D'Alton 1910; Foster 1989, 1993; Gallagher 1988). The cottiers on conacre plots (sharecroppers), the rural proletariat in hopeless arrears to landlords, and the wandering poor (predominantly in the west of Ireland) bore the brunt of the disaster. In other words, the Great Famine slaughtered or drove off the island those Irish men and women most marginal or excluded from the market economy - the circulation of currency and commodities. Economic and infrastructural expansion, and these radical demographic shifts, laid the groundwork for the development of the island as an economic unit integrated within a stratified imperial system.

Perhaps it is not surprising, then, that, alongside his fondness for organs of coercion, Mr. Peel understood modernizing Ireland in terms of integrating it economically into the United Kingdom. One of the final moments of Peel's public career, for example, was the opening of an Industrial Museum for Ireland, where the products and techniques of the machine age could be displayed for the edification of the Irish (Dublin University Magazine 1853). These artifacts were mostly derived from the World's Fair held in Dublin earlier that year, whose iconography stressed the rebirth of Ireland into a new dawn of modernity after the Famine (Saris in press).

At least some designers of Irish asylums took Peel's and the colonial state's dual interests in discipline and economic modernization to heart in their descriptions of their project. A factory metaphor figures prominently in discussions of such institutions. The idea of working on the raw material of inmates in order to fashion or refashion them into productive citizens is the most popular deployment of this trope illustrated in the following extract: 
Inere are also detacned blocks on ine system so much advocated by the highest authorities on insanity .... To these detached blocks or buildings, the patients who show symptoms of improvement can be removed, there to meet with those less afflicted than they have been accustomed to mingle with, and thence when further improvement takes place, to another block, where less insanity may be found than in that which they left. [The Irish Builder 1869:135]

A patient's progress was meant to be physically traceable at the Monaghan District Lunatic Asylum, each spot on the line evidencing relatively more rational behavior and relatively less insanity.

In his concluding remarks on panopticism in Discipline and Punish: The Birth of the Prison, Michel Foucault asks the rhetorical question, "Is it surprising that prisons resemble factories, schools, barracks, hospitals, which all resemble prisons?" (1979:228). This question condenses his argument about the emergence of a new disciplinary episteme. The anonymous author of The Irish Builderwho saw precisely a sort of factory in the spatial layout of the Monaghan mental hospital would have understood Foucault's point. The logic of such models developed out of an equation of the unrefined, the disordered, and the valueless. The model was made familiar through physical and spatial practices that disciplined persons and environments into new forms of existence. Such models have a particular valence in contemporary discussions of colonial regimes in Ireland. Indeed, this equation of the unrefined, the disordered, and the valueless could be replicated time and again in 16th-to-19th-century representations of Ireland and Irish people. The reformation of the disordered rationality of inmates, then, took place in a 19th-century colonial setting in which rulers had long taken for granted an association between various forms of disorder and the local population; they also consciously connected the reformation of this disorder to modernization and economic development.

\section{thinking with money}

There are suggestive resonances between Terry's commodified understandings of the crises in the lives of John and Victor, the historical justification of the mental hospital system in Ireland, and the intellectual models developed around specific asylums to clarify their workings. Their discursive echoes become even more interesting when one considers how people around Kilronan today discuss individuals associated with the mental hospital. They use the phrase "not the full shilling" to refer to people who have been committed to or spent time in the asylum. The oldest of my informants (two in their mid-nineties at the time of my first field visit), for example, remember this phrase being in common use during their youth. As I could find no documentary evidence about the term in local historical sources and because this phrase does not appear to be an Irish idiom that has been translated into English, it seems likely that it emerged in the Sligo region in the 19th century as part of the adoption of English as the first language for the majority of the population. This admittedly rough and somewhat speculative date is supported by the observation that one of the other consistent uses of the shilling in Irish historical sources and modern Hiberno-English is also connected to a state institutional structure, the British Army. Thus, to this day, the expression, "taking the Queen's (or King's) shilling" means to become a recruit for the armed forces of the British crown. This phrase was almost certainly imported into Ireland during the Napoleonic wars: Great Britain recruited heavily in peripheral areas of Ireland recently made accessible by the Act of Union (1801). ${ }^{19}$

Importantly, both these older people (and almost all of my other informants) also agreed that a person who had been in "the Mental" would nearly always have been referred to as "not the full shilling," whereas a person who was just acting irrationally merely might be labeled so. Both documentary evidence and local historical memory also show that from the 1870 s onward, less than 20 years after the opening of the mental hospital, work gangs composed of inmates from the Sligo-Leitrim institution were in some demand from more successful farmers in the 
countryside. ${ }^{20}$ Such farmers were almost certainly emerging capitalist peasants, who were exceeding the labor demands that could be placed on kin networks through the cooring system or who were looking for a way out of the mutual obligations that such a system entailed. Smaller farmers would have no need of such gangs, while most of the gentry would still have had access to "duty days" from tenants during this period. ${ }^{21}$

At one level, then, not the full shilling highlights a setting of increasingly market-oriented farmers who still originated from a peasant stratum and transacted their (relatively few) commodity relationships predominantly in shillings and pence. Workers from the asylum gangs were probably both a bargain and a burden in terms of their labor power-free in a certain sense but unpredictable with respect to both the amount of work that could be expected of them and the amount of surveillance required to extract it. Indirect evidence supports this interpretation of "not the full shilling." Early- to mid-19th-century sources rate a day's labor in most parts of Ireland at about one shilling (Barrow 1975:26). The labor value of the shilling also has literary support in mid- to late-19th-century sources. The English author Anthony Trollope, who spent much of his life (and set many of his novels) in Ireland, writes in The Belton Estates, "Every shilling spent in the house did its full twelve pennies worth of work" (1986:9)--metaphorical confirmation of this house's smooth running efficiency. Minimally, then, shillings existed in Ireland and Britain as a potential resource to model notions of value and economic reasonableness.

"Not the full shilling," however, is also freighted with many more interesting meanings. Ironically, in both the asylum and the army examples, the exchange value of the shilling looks like its least important attribute at the local level. Even if paid, for instance, where was a confined lunatic likely to encounter the free market? The exchange value of the Queen's shilling is similarly compromised, insofar as it marked the transformation of a peasant into a soldier, along with his physical removal (generally for many years) from the locality. Instead of just the market or exchange, the shilling symbolically connotes that people could be reproduced and exchanged in certain roles (that is, a soldier $=$ a soldier), along with an abstract sense of their productivity (higher and lower expectations of a day's work) and, most importantly, a strong sense of their connection to a state system.

The fact that not the full shilling is still the most likely designation for someone who has been treated by the mental hospital-a better description, according to most locals, of someone who has been committed to the asylum than other terms available-is, therefore, very interesting. Hiberno-English, for example, has many terms suitable for such use. Such an individual might be referred to as inseach (Irish for idiot, foolish person), away with the birds (or fairies), eejit, queer, or odd, but, in my experience at least, not the full shilling is almost guaranteed to be applied to someone who has been in St. Columba's Mental Hospital, whereas the others are not. To put it another way, most of my informants saw a certain appropriateness of this phrase for someone who had been in the mental hospital. At the same time, the phrase is also popular among young people in both Sligo town and Kilronan, a quick way of assessing and dismissing a person who (for whatever reason) seems to serve no useful purpose.

Finally, not the full shilling is often considered a fairly serious insult. Thus, others among my consultants, mostly relatives of patients at St. Columba's, who are themselves active in a nongovernment organization that advocates on behalf of the mentally ill, easily referred to not the full shilling as an unfortunate "traditional turn of phrase," a hangover of an older, less enlightened way of thinking of the mentally ill that adds considerably to the heavy burden under which a family with a member so afflicted already operates. These individuals also run educational projects in schools and other venues to diffuse what they see as more enlightened attitudes toward the mentally ill among a population they consider "behind the times" in this regard. 
Money, Simmel points out, is "the specific realization of what is common to economic objects" (1990:120). He also imagines that the logic of economic calculation inevitably acted as a solvent, the universality of exchange constantly eroding the specificity of use-yielding an increasingly homogenized and rationalized modernity. In current speculation about money, however, anthropologists and others have developed more senses of alternative regimes of value, of which any specific currency can become a part. Such alternatives complicate simple binarisms such as traditional and modern (Taylor 1992; Zelizer 1994; for critique, see Weiss 1997). Similar themes have also been examined in Kenya (Parkin 1979), in the notion of labor and life in South Africa (Comaroff and Comaroff 1991, 1992), in the Shetland Islands (Cohen 1979), and in Nuerland (Hutchinson 1996) and can no doubt be found in many other places. The data reviewed in this article, however, allow a glimpse of how the specific rationality associated with commodity logic and modernization can also be imported into, or at least sustained at, a periphery by other than strictly market means. In many places in the world, such means involve configurations of state institutions. The particular properties of these institutions, and the various ways that they are domesticated by some of the local forces that they seek to supplant, will influence the specific modernity under discussion.

In this way, individuals from an area without any great acquaintance with, say, factory production can develop a sophisticated dialogue with some of the postulates that motivate its specific rationality. Both the dialogue and the conflict, however, develop around the actual institutional organs through which a specific type of rationality is imported, and around which resistance forms, in local moral worlds. These institutional organs, then, are sites of -and the raw material for-stubborn structural persistence and complex historical change. Thus, within a decade or two after the opening of the asylum in Sligo town, ambitious local farmers in the area saw the potential of the inmate population for their own entrepreneurial plans, becoming early examples of progressive farmers. ${ }^{23} \mathrm{~A}$ century later, persons connected to this asylum still find themselves intimately intertwined with a highly commodified discourse as a measure of personhood. During this same period, however, the asylum underwent a number of radical reinterpretations, some of which I have explored in other studies (Saris 1996, 1997). Even the scientific knowledge and technical expertise the asylum was interested in inculcating at the locality were not immune to this process. Thus, at the moment, the mental hospital has at least one saint in its collective memory-Tom Fallon-even as it tries to alter the life of another outside of its walls-John McTaggert-through a new institutional technology-community psychiatric nurse Terrence O'Donnell, who is himself only ambiguously described as traditional or modern.

Such local complexity highlights the serious limitations of a temporal watershed dividing the traditional from the modern and a rigid spatial separation between the local and the cosmopolitan. Instead, the asylum demonstrates how various elements within a local moral world are at once structured with respect to one another while at the same time clearly being the current end point of a historical process. Such structures bear the marks of historical transformations, but they also carry such transformations into a present. These transformed and transforming structures are also the very stuff of local history - there is no place else for such history to resicle. Terms like not the full shilling, then, do not continue because a triumphant and abstract modernity is mopping up the last remnants of a static traditional belief system. Instead, the phrase exists as a signpost in a local moral world, pointing to complex local notions of labor, livelihood, and life-and serious conflicts around them.

- To this extent, bureaucratic structures like the asylum were integral to a specific Irish modernity, part of whose distinctiveness was precisely the partial domestication of originally high profile colonial institutions, from the asylum to the army, and their associated technologies 
(see also Cooper and Stoler 1998). Understanding such institutional structures, in the sense of being able to follow their local effects as historical changes while at the same time being able to read the inscriptions that local hands have graven upon them, is a path to understanding this modernity. Thus, the development of an institutional system in the early 1800 s, the building of a particular institution in the mid-1800s, and the dispersal and reinvention of its technologies at the end of the 20th century are nothing more or less than the cultural production of history and the historical production of culture (Gulliver and Silverman 1995; Ohnuki-Tierney 1990; Sahlins 1985,1995$)$. One of my nurse consultants and a friend, the late John Hamilton (to whom this article is dedicated) put it better and more elegantly. While strolling through the hospital grounds and reflecting on one of my many questions about his 35-year career with the Health Services (including more than 20 at St. Columba's), as well as my seemingly insatiable curiosity about the influences of (and on) the institution, he looked up at the Old Building and said wryly, "You've got to hand it to the British. They built them well. They built them to last."

\section{notes}

Acknowledgments. I am most indebted to John Hamilton, a mental hospital nurse, consultant, and friend, for the initial inspiration for this essay. He died just before I defended my dissertation. The research itself was made possible by support from the American Council of Learned Societies and the Social Science Research Council Doctoral Research Program for Western Europe (1988-90). I also owe thanks to the Charlotte W. Newcombe Foundation for write-up support (1991-92). I presented early drafts of this article to the Department of Social Science, University College Cork, and to the Anthropology/Sociology Seminar at the National University of Ireland, Maynooth. The article benefited from the comments that I received in both places. Finally, I would like to extend particular thanks to those who read various versions of this work and provided helpful feedback, particularly Raymond Fogelson, Jean Comaroff, James Fernandez, Byron Good, Steve Coleman, Stuart McLean, Lisa McCaffrey, and three anonymous reviewers. Special thanks to Eamon Slater for assistance with sources. Any remaining mistakes and omissions are, of course, entirely my own.

1. All names and places in this work, with the exception of John Hamilton, St. Columba's Hospital, Sligo town, and Counties Sligo, have been changed to protect the anonymity of informants.

2. Well into the 20th century, Ireland, qua national demographic entity, supported one of the highest per capita mental hospital populations in the world. This population, alongside the elevated use of such diagnostic categories as schizophrenia and alcoholism, particularly in the poorer western portions of the island, has been the subject of much international theorizing (Clare 1991; Corbett 1874; Dawson 1911; Murphy 1975; Robins 1986; Scheper-Hughes 1982; Walsh 1968; World Health Organization 1973; Yousef, Kinsella, and Waddington 1991).

3. Curtin (1986) has summarized the bones of this debate as follows: on the one hand, Peter Gibbon attacks the decline of sociology of rural Ireland, such as Brody's work Inishkillane: Change and Decline in the West of Ireland (1973), as the rediscovery of historical trends that Arensberg and Kimball missed in the 1930 s due to their inability to see beyond their functionalist blinders. On the other hand, Damien Hannan (1979) defends Arensberg's findings, stressing how, until quite recently, much of the Irish peasantry has in fact held onto a traditional way of life, relatively separate from the market and its associated modern mentality. Curtin resolves the debate by agreeing with parts of both arguments, including Gibbon's sense of the historical depth of market penetration in rural Ireland and Hannan's appreciation of the explanatory power of Arensberg and Kimball's steady-state system to account for how long many people managed to stay on the land (in defiance of the market). See also Wilson 1984 for an overview of the debate and Healy 1989 for a very bleak insider view of local dynamics in rural Ireland.

4. For studies addressing similar issues, see Appadurai 1986; Comaroff and Comaroff 1991, 1992; and Hutchinson 1996.

5. Bord Fáilte is the official state organization in the Republic of Ireland promoting tourism.

6. Saint is, of course, first and foremost a religious term. Its resonances in rural Ireland have recently attracted anthropological interest once again (Taylor 1995). John's interests and ability at least in part call to mind some of the powers attributed to the drunken priest, that is, someone with an indifference to established hierarchies able to control certain seemingly eldritch forces for local gain or loss (Taylor 1995:143-166, especially 155-157).

7. St. Columba's Hospital in Sligo is directionally "down below" from Kilronan, a direct translation of an Irish idiom. In the country parts around Kilronan, gone down below can serve as a sort of euphemism for asylum committal.

8. This is, the Big House, the main (original) building, which, by the time of this recollection, had several ancillary structures on its grounds. By this time, it also served as the institution's "Back Ward," so having an "uncle down the House" implied having a relative who had been in the institution for some time and who seemed likely to be there for much longer. 
9. Remembering the social atmosphere of the asylum in the middle part of this century, one older nurse described the resident medical superintendent as "being the closest thing to God." The rest of the medical staff also demanded and received deference, expecting and receiving formal salutes, for example, well into the 1960s.

10. "Losing one's courage" is a translation of an Irish idiom, "A mhisneach a bhaint de dhuine lor" (to make someone lose courage). The sense of the phrase in English is "to depress someone." In my experience, the highest praise that many older people can give a psychiatrist in English is not that they were cured of depression, or even that they were feeling better because of treatment, but that the professional restored their courage.

11. This is a serious chronic respiratory condition caused by certain species of mold found in hay. Its severity ranges from debilitating to fatal.

12. This is not to say that no interests were served under the old system. Indeed, the first instantiation of a formal Cattle Mart in Kilronan was eventually defeated by a coalition of publicans, who reckoned (probably rightly) that the new institution was likely to hurt their custom. A second start of the Mart in the mid-1950s was successful.

13. If the importance of a quote can be judged from the frequency of its citation, then Browne's testimony is very important indeed. It is cited approvingly in the introductions of the reports of commissions convened in 1843, 1879, and 1890-91. It became a critical image of the suffering of the insane in 19th-century rural Ireland, a place where, if suffering could somehow be quantified and scaled, any number of images might have attracted as much official sympathy.

14. It is important to understand that Denis Browne was no sympathetic do-gooder, removed from the rough and tumble of political life of Mayo. He was instead an adept at power-a confirmed election rigger, an inveterate jobber-and, from the beginning of his career, he had a reputation as a hanging judge (Select Committee on the County Mayo Election 1784). His ruthlessness toward the peasantry in his locale, however, was peculiarly tempered when it came to the pauper lunatic. He contributed to the support of the Bridewell in Castlebar, which housed the lunatics that Browne, in his capacity as magistrate, felt could be cared for more or less locally. He made good faith efforts to see that those he felt he had to send to the capital were treated humanely. Indeed, he was so incensed when he discovered that several of his charges were not accounted for that he personally investigated, at his own expense, the lunatic wards of the Dublin House of Industry, an investigation that the institution took seriously enough to issue a point-by-point explanation of their disappearance (State Paper Office 1817).

15. Both "Peelers" in Ireland and "Bobbies" in England are derived from the name of Robert Peel. The variable acceptance of such instruments in the two settings is nicely coded in the choice of popular nicknames (Christian or surname) for these internal security forces.

16. This exercise in domination is brilliantly fictionalized and explored in Brian Friel's play Translations. For a very different reading of the Ordinance Survey, however, see Anderson 1975.

17. Houses of Industry were locally run, nonspecific confinement centers housing the poor, the insane, able-bodied prostitutes, and orphans.

18. The postfamine period was marked by high rates of church attendance, an explosion in the number of new churches built, and the solidification of central control of Catholicism in Ireland (see also Taylor 1995).

19. I would like to thank one of my students, Tom Kelley, for leading me to think seriously about this use of shilling in Ireland.

20. See Journal of Mental Science 1893:319, Board of Governors of the Sligo-Leitrim District Lunatic Asylum 1854-1925: August 1879, August 1885, September 1895. Dr. Petit, the resident medical superintendent at that time, thought that such trips were beneficial to the inmates insofar as they broke down "the old prejudice and fear of lunatics among the public out of doors" (Journal of Menta/ Science 1893:319).

21. Cooring is the name in Ireland for a cooperative farm labor system involving neighbors and families (Arensberg and Kimball 1940:75-77).

22. The Irish version of the Old French custom of corvée.

23. The farm attached to Sligo-Leitrim institution was also progressive in the local sense. From the $1880 \mathrm{~s}$ into the 1970s, it served as home for the countywide agricultural fair, where the most current and efficient agricultural techniques were showcased and contests were held to see who could plow the most land in a given amount of time (Saris 1996:546).

\section{references cited}

\section{Anderson, John Harwood}

1975 A Paper Landscape: The Ordinance Survey in Nineteenth-Century ireland. Oxford: Clarendon Press. Appadurai, Arjun

1986 Introduction: Commodities and the Politics of Value. In The Social Life of Things: Commodities in Cultural Perspective. Arjun Appadurai, ed. Pp. 3-63. Cambridge: Cambridge University Press.

1988 Putting Hierarchy in Its Place. Cultural Anthropology 3(1):36-49.

1996 Modernity at Large: Cultural Dimensions of Globalization. Minneapolis: University of Minnesota Press.

Arensberg, Conrad

1937 The Irish Countryman. Cambridge, MA: Macmillan. 
Arensberg, Conrad, and Solon Kimball

1940 Family and Community in Ireland. Cambridge, MA: Harvard University Press.

Arnold, David

1988 Imperial Medicine and Indigenous Societies. Manchester: Manchester University Press.

Barrow, Gerard L.

1975 The Emergence of the Irish Banking System: 1820-1845. Dublin: Gill and Macmillan.

Bendix, Regina

1997 In Search of Authenticity: The Formation of Folklore Studies. Madison: University of Wisconsin Press.

Board of Governors of the Sligo-Leitrim District Lunatic Asylum.

1854-1925 Minutes of the Meetings of the Board of Governors of the Sligo-Leitrim District Lunatic Asylum. Dublin: State Paper Office.

Brody, Hugh

1973 Inishkillane: Change and Decline in the West of Ireland. London: Jill Norman and Hobbhouse Ltd.

Broeker, Galen

1970 Rural Disorder and Police Reform in Ireland, 1812-1836. London: Routledge and Kegan Paul.

Butchart, Alexander

1998 The Anatomy of Power: European Constructions of the African Body. London: Zed Books.

Clare, Anthony

1991 The Mad Irish? In Mental Health in Ireland. Colm Keane, ed. Pp. 4-17. Dublin: Gill and Macmillan and Radio Telefís Éireann.

Cohen, Anthony

1979 The Whalsey Croft: Traditional Work and Customary Identity in Modern Times. In Social Anthropology of Work. Sandra Wallman, ed. Pp. 249-267. London: Academic Press.

Comaroff, John, and Jean Comaroff

1991 Of Revelation and Revolution: Christianity, Colonialism and Consciousness in South Africa. vol.

1. Chicago: University of Chicago Press.

1992 Ethnography and the Historical Imagination. Boulder, CO: Westview Press.

Cooper, Frederick, and Ann Laura Stoler

1998 Tensions of Empire: Colonial Cultures in a Bourgeois World. Berkeley: University of California Press.

Corbett, William

1874 On the Statistics of Insanity, Past and Present. Journal of the Statistical and Social Inquiry Society of Ireland 6:382-394.

Cresswell, Robert

1969 Une communauté, rurale de l'Irlande. Paris: Institute d'Ethnologie.

Curtin, Chris

1986 The Peasant Family Farm and Commoditization in the West of Ireland. In The Commoditization

Debate: Labor, Process Strategy and Social Network. Norman Long, ed. Pp. 58-121. Wageningen:

Agricultural University of Wageningen.

Curtis, Liz

1994 The Cause of Ireland: From the United Irishmen to Partition. Belfast: Beyond the Pale Publicatioins.

Curtis, L. Perry, Jr.

1971 Apes and Angels: The Image of the Irishman in Victorian Caricature. Washington, DC: Smithsonian Institution Press.

D'Alton, Rev. E. A.

1910 History of Ireland from the Earliest Times to the Present Days. 6 vols. London: The Gresham Publishing Co.

Dawson, William R.

1911 The Presidential Address on the Relation between the Geographical Distribution of Insanity and That of Certain Social and Other Conditions in Ireland. Journal of Mental Science 57(3):538-597.

Dublin University Magazine

1853 Museum of Irish Industry. Dubliln University Magazine 62(248):230-244.

Farmer, Paul

1992 Aids and Accusation: Haiti and the Geography of Blame. Berkeley: University of California Press.

Feingold, William L.

1984 The Revolt of the Tenantry: The Transformation of Local Government in Ireland, 1872-1886.

Boston: Northeastern University Press.

Finnane, Mark

1981 Insanity and the Insane in Post-Famine Ireland. London: Croom Helm.

Fogelson, Raymond D.

1989 The Ethnohistory of Events and Nonevents. Ethnohistory 36(2):134-147.

Foster, Robert Fitzroy

1989 Modern Ireland: 1600-1972. London: A. Lane.

1993 Paddy and Mr. Punch: Connections in Irish and English History. London: A. Lane. 
Foucault, Michel

1979 Discipline and Punish: The Birth of the Prison. New York: Vintage Books.

Gallagher, Thomas

1988 Paddy's Lament: Ireland 1846-1847. Prelude to Hatred. Swords, Ireland: Poolbeg Press.

Gibbon, Peter

1973 Arensberg and Kimball Revisited. Economy and Society 2(4):479-498.

Gulliver, Philip H., and Marilyn Silverman

1995 Merchants and Shopkeepers: A Historical Anthropology of an Irish Market Town, 1200-1991.

Toronto: University of Toronto Press.

Habermas, Jürgen

1984 Theory of Communicative Action Vol. I: Reason and the Rationalization of Society. Thomas McCarthy, trans. Boston: Beacon Press

1987 Theory of Communicative Action Volume II. Thomas McCarthy, trans. Cambridge: Polity Press.

Hannan, Damien

1979 Displacement and Development: Class, Kinship and Social Change in Irish Rural Communities.

Dublin: Economic and Social Research Institute.

Hazelkorn, Ellen

1989 Capital and the Irish Question. Science and Society 53(1):1-35.

Healy, John

1989[1968] No One Shouted Stop (formerly The Death of an Irish Town). Achill, Ireland: The House of Healy.

Hutchinson, Sharon Elaine

1996 Nuer Dilemmas: Coping with Money, War, and the State. Berkeley: University of California Press. Inglis, Thomas

1991 The Struggle for Control of the Irish Body: State, Church, and Society in Nineteenth-Century Ireland. In Religious Regimes and State Formation. Eric Wolf, ed. Pp. 55-72. Albany: State University of New York Press.

Irish Builder

1869 Monaghan and Cavan, New Lunatic Asylums. Irish Builder 11(227):135.

Journal of Mental Science

1893 Notes and News, Irish Quarterly Meeting. Journal of Mental Science 139:315-320.

Kiely, Benedict

1977 A Journey to Seven Streams and Other Stories. Dublin: Poolbeg Press.

Larcom Papers

1865 Memo from Dublin Castle, Concerning the Administration of the Lunatic Asylums, 30 April, 1865.

National Library of Ireland Manuscripts. Dublin: National Library of Ireland.

Larkin, Emmet

1972 The Devotional Revolution in Ireland. American Historical Review 77(3):625-652.

Lebow, Richard Ned

1976 White Britain and Black Ireland: The Influence of Stereotypes on Colonial Policy. Philadelphia:

Institute for the Study of Human Issues.

Lee, Joseph

1973 The Modernisation of Irish Society, 1848-1918. Dublin: Gill and Macmillan.

MacDonagh, Oliver

1977 Ireland: The Union and Its Aftermath. London: George Allen and Unwin.

Marx, Karl

1972 Capital: A Critique of Political Economy. Friedrich Engels, ed. London: Lawrence and Wishart.

Mulligan, Fergus

1983 One Hundred and Fifty Years of Irish Railways. Belfast: Appletree Press.

Murphy, H. B. M.

1975 Alcoholism and Schizophrenia in the Irish: A Review. Transcultural Psychiatric Research Review 9:116-139.

Ohnuki-Tierney, Emiko, ed.

1990 Culture through Time: Anthropological Approaches. Stanford: Stanford University Press.

Parkin, David J.

1979 The Categorization of Work: Cases from Coastal Kenya. In Social Anthropology of Work. Sandra

Wallman, ed. Pp. 317-335. London: Academic Press.

Robins, Joseph

1986 Fools and Mad: A History of the Insane in Ireland. Dublin: The Institute for Public Administration.

Sahlins, Marshall

1976 Culture and Practical Reason. Chicago: University of Chicago Press.

1985 Islands of History. Chicago: University of Chicago Press.

1995 How Natives Think: About Captain Cook, for Example. Chicago: University of Chicago Press.

Saris, A. Jamie

1994 The Proper Place for Lunatics: Asylum, Person, and History in a Rural Irish Community. Ph.D. dissertation, Dept. of Anthropology, University of Chicago. 
1996 Mad Kings, Proper Houses, and an Asylum in Rural Ireland. American Anthropologist 98(3): 539-554.

1997 The Asylum in Ireland: A Brief Institutional History and Some Local Effects. In Readings in the Sociology of Health and IIIness in Ireland. Anne Cleary and Margaret P. Tracy, eds. Pp. 208-223. Dublin: University College Press.

1998 William S. Hallaran, Late Eighteenth-Century Asylum-Keeper. Paper presented at the annual meeting of the Eighteenth-Century Society of Ireland, Ballymahon, Ireland. May 7-9.

In press Imagining Ireland in the Great Irish Exhibition of 1853. In Regionalism and Nineteenth-Century Ireland. Leon Litvak and Glen Hooper, eds. Dublin: Four Courts Press.

Scheper-Hughes, Nancy

1982 Saints, Scholars, and Schizophrenics. Berkeley: University of California Press.

Select Committee on the County Mayo Election

1784 Minutes of Evidence Taken before the Select Committee on the County Mayo Election. Dublin.

Select Committee to Consider the State of the Lunatic Poor in Ireland

1817 Report with Minutes and Appendices. Dublin: Alexander Thom.

Shutes, Mark

1987 Production and Social Change in a Rural Irish Parish. Social Studies 9(3-4):17-28.

1989 Changing Agricultural Strategies in a Kerry Parish. In Ireland from Below: Social Change and Local

Communities. Chris Curtin and Thomas Wilson, eds. Pp. 186-206. Galway: University of Galway Press.

Simmel, Georg

1990 The Philosophy of Money. 2nd Enlarged Edition. Tom Bottomore and David Frisby, trans. London: Routledge Press.

State Paper Office

1817 Official Papers 451/6. Dublin Castle, Dublin, Ireland.

Taylor, Christopher

1992 Milk, Honey and Money. Washington, DC: Smithsonian Institution Press.

Taylor, Lawrence J.

1995 Occasions of Faith: An Anthropology of Irish Catholics. Dublin: The Lilliput Press.

Thompson, David

1974 Woodbrook. London: Vintage.

Trollope, Anthony

1986[1865] The Belton Estate. Oxford: Oxford University Press.

Walsh, Dermot

1968 Hospitalized Psychiatric Morbidity in the Republic of Ireland. British Journal of Psychiatry $114(1): 11-14$.

Weber, Max

1976 The Protestant Ethic and the Spirit of Capitalism. 2nd edition. Talcott Parsons, trans. London: Allen and Unwin.

1978 Economy and Society: An Outline of Interpretive Sociology. Ephraim Fischoff, trans. Berkeley: University of California Press.

Weiss, Brad

1997 Northwestern Tanzania on a Single Shilling: Sociality, Embodiment, Valuation. Cultural Anthropology 12(3):335-361.

Wilson, Thomas

1984 From Clare to the Common Market: Perspectives in Irish Ethnography. Anthropological Quarterly $57(1): 1-15$

World Health Organization

1973 International Pilot Study of Schizophrenia. Geneva.

Youssef, Hanafy, Anthony Kinsella, and John Waddington

1991 Evidence for Geographical Variations in the Prevalence of Schizophrenia in Rural Ireland. Archives of General Psychiatry 48(4):254-258.

Zelizer, Vivian

1994 The Social Meaning of Money: Pin Money, Paychecks, Poor Relief and Other Currencies. New York: Basic Books.

accepted March 11, 1998

final version submitted July 8,1998

A. Jamie Saris

Department of Anthropology

National University of Ireland

Maynooth, Co. Kildare

Ireland

ajamie.saris@may.ie 